\title{
Determination of acute toxicity of ammonium in juvenile Patagonian blenny (Eleginops maclovinus)
}

\author{
A. Mardones ${ }^{a, b *}$, M. González ${ }^{c}$, C. Rivas-Mancilla ${ }^{d}$, R. Vega ${ }^{a, b}$, A. Augsburger ${ }^{\prime}$, F. Encina ${ }^{e, f}$ and \\ P. De los Ríos ${ }^{e, g}$
}

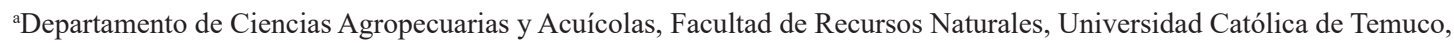
P.O. Box 15-D, Temuco, Chile

${ }^{b}$ Núcleo de Investigación en Producción Alimentaria UC Temuco, P.O. Box 15-D, Temuco, Chile

${ }^{\mathrm{c} C M P C}$ Celulosa, Panamericana Sur, Km 471, Laja, Chile

${ }^{d}$ Universidad Santo Tomás, Buena Vecindad 91, Esquina Egaña, Puerto Montt, Chile

e Departamento de Ciencias Ambientales, Facultad de Recursos Naturales, Universidad Católica de Temuco, P.O. Box 15-D, Temuco, Chile

fNúcleo de Estudios Ambientales UC Temuco, P.O. Box 15-D, Temuco, Chile

${ }^{g}$ Departamento de Ciencias Biológicas y Químicas, Facultad de Recursos Naturales, Universidad Católica de Temuco. P.O. Box 15-D, Temuco, Chile

e-mail:mardolaz@uct.cl

Received: October 24, 2017 - Accepted: March 22, 2018 - Distributed: November 30, 2019

\begin{abstract}
Deionized ammonium $\left(\mathrm{NH}_{3}\right)$ acute toxicity $\left(\mathrm{LC}_{50-96 \mathrm{~h}}\right)$ in Patagonian blenny juveniles (Eleginops maclovinus) was assessed. Concentrations of deionized ammonium in salt water were prepared by using $24.09 \pm 2.1 \mathrm{~g}$ ammonium chloride $\left(\mathrm{NH}_{4} \mathrm{Cl}\right)$. Fish were exposed in triplicates to different ammonium concentrations: $0.05 ; 0.094 ; 0.175 ; 0.325$ and $0.605 \mathrm{mg} \mathrm{NH}_{3} \mathrm{~L}^{-1}$. Additionally, a control group was included. Experimental fish were kept at a photoperiod of 16:8h. Average temperatures were $16.24 \pm 1.40{ }^{\circ} \mathrm{C}$. Oxygen concentration was $7.16 \pm 0.40 \mathrm{mg} \mathrm{L}^{-1}$. Water $\mathrm{pH}$ was $7.89 \pm 0.2 . \mathrm{LC}_{50-96 \mathrm{~h}}$, was estimated by using Probit statistical method (95\% intervals) using EPA software (1993). Juveniles of E. maclovinus showed a $\mathrm{LC}_{50-96 \mathrm{~h}}$ of $0.413 \mathrm{mg} \mathrm{NH}_{3} \mathrm{~L}^{-1}$ value, different from most marine species. This study presents the first record of ammonium toxicity in marine species of Chile.
\end{abstract}

Keywords: acute toxicity, Eleginops maclovinus, $\mathrm{LC}_{50-96 \mathrm{~h}}$.

\section{Determinação da toxicidade aguda do amônio em Babosas-da-Patagônia (Eleginops maclovinus) juvenis}

\section{Resumo}

A toxicidade aguda $\left(\mathrm{LC}_{50-96 \mathrm{~h}}\right)$ de amônia deionizada $\left(\mathrm{NH}_{3}\right)$ em Babosas-da-Patagônia (Eleginops maclovinus) juvenis foi avaliada. As concentrações de sal de amônia deionizada em água foram preparados com $24,09 \pm 2,1 \mathrm{~g}$ de cloreto de amônio $\left(\mathrm{NH}_{4} \mathrm{Cl}\right)$. Os peixes foram expostos em triplicata a diferentes concentrações de amônia: 0,05; 0,094; 0,175; 0,325 e 0,605 mg L-1 de $\mathrm{NH}_{3}$. Além disso, um grupo de controle foi incluído. Peixes experimentais foram mantidos em fotoperíodo de

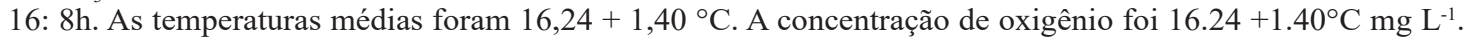
$\mathrm{O}$ pH da água foi de 7,89+0,2. h $\mathrm{LC}_{50-96 \mathrm{~h}}$, foi estimada usando o método estatístico de Probit (intervalos de 95\%) usando o software EPA (1993). E. maclovinus juvenis apresentaram uma $\mathrm{LC}_{50-96 \mathrm{~h}}$ de $0.413 \mathrm{mg} \mathrm{NH}_{3} \mathrm{~L}^{-1}$ valor diferente da maioria das espécies marinhas. Este estudo apresenta o primeiro registro de toxicidade amónio em espécies marinhas do Chile.

Palavras-chave: toxicidade aguda, Eleginops maclovinus, $\mathrm{LC}_{50-96 \mathrm{~h}}$.

\section{Introduction}

Altough the salmon and trouts are the main exportation products from Chilean aquaculture, the urgent aquaculture diversification of Chilean fish farming is necessary. Currently, the Chilean aquaculture production has a $98 \%$ FOB in salmon farming, and only the $3.2 \%$ includes other

species. The "Patagonian blenny" (Eleginops maclovinus, Georges Cuvier, 1830) is an endemic species with high potential for aquaculture production (Sa et al., 2014).

The E. maclovinus belongs to Percifirmes order and it is distributed in Pacific Ocean from Valparaiso $\left(33^{\circ} \mathrm{S}\right)$ 
to Tierra del Fuego island $\left(54^{\circ} \mathrm{S}\right)$ and in the Atlantic Ocean until Buenos Aires province ( $39^{\circ} \mathrm{S}$ ) (Calvo et al., 1992), and was reported around Falkland islands. It is a prothandric hermaphrodite with sexual reversion in function of its corporal size and age, under intraspecific competence (Licandeo et al., 2006). It is an omnivorous species and its diet varies according to geography, substrate and season (Pavez et al., 2005).

An intensive production system requires adequate environmental conditions that promote growth and development of all organisms and in this context it is necessary for each species such as dissolved oxygen, carbon dioxide and total ammonium (TAN) that determine the success of the fish farming activities (Rakocy et al., 1992; Gerber et al., 2015; Zhou et al., 2017; Silva et al., 2018). The total ammonium is the total sum of ammonium $\left(\mathrm{NH}_{4}^{+}\right)$and ammoniac $\left(\mathrm{NH}_{3}\right)$, the latter is considered a product of body protein and nucleic acid biochemical degradation (Verbeeten et al., 1999; Shrivastava et al., 2017; Xiang et al., 2016). Eddy (2005) informed that the ammoniac tolerance in freshwater fishes varied between 0.068 and $2.00 \mathrm{mg} \mathrm{NH}_{3} \mathrm{~L}^{-1}$ and between 0.09 and $3.35 \mathrm{mg} \mathrm{NH}_{3} \mathrm{~L}^{-1}$ in marine fishes. In theleost fishes the nitrogen is normally eliminated through gills and urine (Carter et al., 1998). The $\mathrm{pH}$ is affected by the presence of ammonium ion or ammoniac (Randall and Tsui, 2002).

The previous turbot studies (Scophthalmus maximus) showed that this species is less tolerant to normoxia condition (80-85\% oxygen saturation), in comparison to tolerance to under hiperoxia condition (110-115\% oxygen saturation) (Foss et al., 2007). These studies agree with Carter et al. (1998) who reported that low oxygen environmental level might enhance the ammoniac toxic effects. An evidence of this factor is the depolarization that is produced in gills under ammoniac presence, simultaneously an excessive ATP consumption by the glutamate receptor activation (NMDA). As a result of intoxication, the individuals have convulsions and dead (Beaumont et al., 1995; Randall and Tsui, 2002). Other ammoniac effects are (Miranda-Filho et al., 1995), alterations in cerebellum tissue (Wajsbrot et al., 1991), increment of respiratory and cardiopulmonary function (Adams et al., 2001), swimming behaviour (Wicks et al., 2002) and loss of fish reproductive capacity (Russo and Thurston, 1998).

The studies of ammonium have been carried out with marine and freshwater fishes. The toxic effects are notoriously different for both groups. Data was obtained from determination of lethal media concentration $\left(\mathrm{LC}_{50}\right)$ that corresponds to the level of $50 \%$ of the population; this is the main procedure (Franson, 2002).

The fish sensibility to ammoniac depends on the species, for example, the $\mathrm{LC}_{50}$ for $S$. maximus juveniles is from 1-7 to $2.7 \mathrm{mg} \mathrm{L}^{-1}$ of ammoniac, and is different compared to 0.2 to $0.7 \mathrm{mg} \mathrm{L}^{-1}$ in salmonid juveniles (Person et al., 2007). There is not available information about ammoniac tolerance for "Patagonian blenny" E. maclovinus. The aim of the present study is to determine the first ecotoxicological parameters, specifically the acute ammoniac toxicity $\mathrm{LC}_{50-96 \mathrm{~h}}$ in E. maclovinus under farming conditions.

\section{Material and Methods}

"Patagonian blenny" E. maclovinus juveniles were obtained from Quillaipe marine station of Fundacion Chile ( $\left.41^{\circ} 31^{\prime} \mathrm{S} ; 72^{\circ} 44^{\prime} \mathrm{W}\right)$. Fish were acclimated during 14 days period prior the experiment. During this period the fishes were fed ad libitum with salmon pellet, this feeding was suspended 48 hours before the experiment. The procedure used was suggested by Franson (2002). For the $\mathrm{LC}_{50-96 \mathrm{~h}}$ determination fish specimens of an average weight $24.09 \pm 2.1 \mathrm{~g}$ were selected and separated in triplicates in a control group, and five experimental groups with five individuals for each experimental units, and these were exposed to starvation during 48 hours. The acute toxicity assay was carried out in a close recirculating system with $0.015 \mathrm{~m}^{3}$ tanks. Each 12 hour the temperature, $\mathrm{pH}$ and oxygen values were measured. The photoperiod used was of 18 hours light: 6 hours dark. The ammoniac and ammonium chloride concentrations were specified in Table 1. Mortality and swimming fish were recorded twice daily and classified as a normal $(\mathrm{N})$, lethargic swimming $(\mathrm{L})$ and dead $(\dagger)$, when no movement in their gills showing no reaction to mechanical stimuli (Weirich and Riche, 2006). Ammonia was monitored at $0 ; 24 ; 48 ; 72$ and $96 \mathrm{~h}$ in according to Solorzano (1969) fide Bayne, 1985). To determine LC50-96h, Probit statistical method was used with a range of $95 \%$ by the program EPA.

\section{Results}

During the experimental period ( $96 \mathrm{hr}$ ) the temperature varied between $16.24 \pm 1.4{ }^{\circ} \mathrm{C}$, the dissolved oxygen concentration in $7.16 \pm 0.40 \mathrm{mg} \mathrm{L}^{-1}, \mathrm{pH}$ between $7.89 \pm 0.20$. The utilized fish individuals in the experiment did not show abnormal behaviour and mortality during acclimatation. There was no mortality in T1 group (fish reared in $0.05 \mathrm{mg} \mathrm{L}^{-1}$ ammoniac concentration). However at $72 \mathrm{hr}$ after the experimental period, the fish from $\mathrm{T} 1$ group showed lethargic swim (Table 2); $48 \mathrm{hr}$ after the experiment beginning, fish showed lethargic swim (Table 2). The group exposed to high ammoniac concentration $\left(0.605 \mathrm{mg} \mathrm{L}^{-1}\right)$ did not show mortality during the experimental period (Table 2). 48 hours after the beginning of experiment, the fish showed lethargic swim (Table 2). 48 hours after the beginning of experiment, both groups showed intoxication effects. The first group T1

Table 1. Concentration ammonium deionized $\left(\mathrm{NH}_{3}\right)$ and ammonium chloride.

\begin{tabular}{ccc}
\hline Treatments & NH3 $\left.\mathbf{m g}^{-1} \mathbf{L}\right)$ & NH4CL $\left(\mathbf{g L}^{-1}\right)$ \\
\hline T 1 & 0.050 & 0.500 \\
T 2 & 0.094 & 0.931 \\
T 3 & 0.175 & 1.732 \\
T 4 & 0.325 & 3.224 \\
T 5 & 0.605 & 6.000 \\
\hline
\end{tabular}


Table 2. Swim behaviour of fish individuals during a $96 \mathrm{~h}$ period.

\begin{tabular}{ccccccc}
\hline \multirow{2}{*}{ mgNH $_{\mathbf{3}} \mathbf{L}^{\mathbf{1}}$} & \multirow{2}{*}{ Treatment } & \multicolumn{5}{c}{ Time } \\
\cline { 3 - 7 } & & $\mathbf{0}$ & $\mathbf{2 4}$ & $\mathbf{4 8}$ & $\mathbf{7 2}$ & $\mathbf{9 6}$ \\
\hline Control & Control & $\mathrm{N}$ & $\mathrm{N}$ & $\mathrm{N}$ & $\mathrm{N}$ & $\mathrm{N}$ \\
0.050 & $\mathrm{~T} 1$ & $\mathrm{~N}$ & $\mathrm{~N}$ & $\mathrm{~N}$ & $\mathrm{~L}$ & $\mathrm{~L}$ \\
0.094 & $\mathrm{~T} 2$ & $\mathrm{~N}$ & $\mathrm{~N}$ & $\mathrm{~N}$ & $\mathrm{~L}$ & $\mathrm{~L}$ \\
0.175 & $\mathrm{~T} 3$ & $\mathrm{~N}$ & $\mathrm{~N}$ & $\mathrm{~N}$ & $\mathrm{~L}$ & $\mathrm{~L}$ \\
0.325 & $\mathrm{~T} 4$ & $\mathrm{~N}$ & $\mathrm{~N}$ & $\mathrm{~L}$ & $\mathrm{~L}$ & $\mathrm{~L}$ \\
0.605 & $\mathrm{~T} 5$ & $\mathrm{~N}$ & $\mathrm{~L}$ & $\dagger$ & $\dagger$ & $\dagger$ \\
\hline
\end{tabular}

Normal (N), 100\% lethargic (L) y 100\% mortality $(\dagger)$.

Table 3. Survival of E. maclovinus juveniles in five deionized ammonium concentration $\left(\mathrm{mgNH}_{3} \mathrm{~L}^{-1}\right)$ during $96 \mathrm{~h}$.

\begin{tabular}{cccc}
\hline $\mathbf{m g N H}_{3} \mathbf{L}^{-1}$ & Treatment & $\mathbf{n}$ & Survival (\%) \\
\hline Control & Control & 5 & $100 \pm 0.0$ \\
0.050 & $\mathrm{~T} 1$ & 5 & $100 \pm 0.0$ \\
0.094 & $\mathrm{~T} 2$ & 5 & $80 \pm 8.0$ \\
0.175 & $\mathrm{~T} 3$ & 5 & $32 \pm 7.0$ \\
0.325 & $\mathrm{~T} 4$ & 5 & $12 \pm 5.0$ \\
0.605 & $\mathrm{~T} 5$ & 5 & $0.0 \pm 0.0$ \\
\hline
\end{tabular}

exposed to low ammoniac concentration $\left(0.050 \mathrm{mgNH}_{3} \mathrm{~L}^{-1}\right)$ was not mortality, whereas the $\mathrm{T} 2\left(0.094 \mathrm{mgNH}_{3} \mathrm{~L}^{-1}\right)$ group had $80 \%$ survival, T3 $\left(0.175 \mathrm{mgNH}_{3} \mathrm{~L}^{-1}\right)$ had $32 \%$ survival, T4 $\left(0.325 \mathrm{mgNH}_{3} \mathrm{~L}^{-1}\right)$ had $12 \%$ survival, and finally $\mathrm{T} 5\left(0.605 \mathrm{mgNH}_{3} \mathrm{~L}^{-1}\right)$ had $100 \%$ mortality after 96 hours (Table 3). Direct correlation between survival time and $\mathrm{NH}_{3}$ was observed and it showed a low survival under high ammoniac concentration. The $\mathrm{LC}_{50-96 \mathrm{~h}}$ ammoniac calculation, for E. maclovinus juveniles was of $0.413 \mathrm{mgNH}_{3} \mathrm{~L}^{-1}$ (the limit at $95 \%$ was between 0.233 to $0.611 \mathrm{mgNH}_{3} \mathrm{~L}^{-1}$ ), that indicated that the same species has low tolerance to ammoniac concentration in comparison to other marine species.

\section{Discussion}

The $\mathrm{LC}_{50-96 \mathrm{~h}}$ for E. maclovinus obtained of $0.413 \mathrm{mgNH}_{3} \mathrm{~L}^{-1}$ (limited at $95 \%$ between 0.233 to $0.611 \mathrm{mgNH}_{3} \mathrm{~L}^{-1}$ ) is comparable with the results obtained for Menidia beryllina that has a $\mathrm{LC}_{50}$ of $0.61 \mathrm{mgNH}_{3} \mathrm{~L}^{-1}$. The tolerance level for other marine species are of $2.29 \mathrm{mgNH}_{3} \mathrm{~L}^{-1}$ for Cyprinodon variegatus and 3.35 for Gateropus aculeatus (Handy and Poxton, 1993). On the basis of these results it can be considered that E. maclovinus has tolerance ranks similar to inland water fishes, such as Oncorhynchus mykiss in example it observed a tolerance level of $0.291 \mathrm{mgNH}_{3} \mathrm{~L}^{-1}$ (Thurston and Russo, 1983), Salmo trutta was of $0.592 \mathrm{mgNH}_{3} \mathrm{~L}^{-1}$, Prosopium williamsoni was of $0.358 \mathrm{mgNH}_{3} \mathrm{~L}^{-1}$ (Thurston and Meyn, 1984), and Ictalurus punctatis that was of $0.50 \mathrm{mgNH}_{3} \mathrm{~L}^{-1}$.

The ammoniac is considered as the most toxic fraction of TAN that is defined by the sum of ammonium ion and ammoniac (EPA, 1998). The ammoniac effect is related to temperature, salinity, oxygen and $\mathrm{pH}$ (Randall and Tsui,
2002; Fang et al., 2017), on this basis, the temperature observed in the present study was, within the optimal tolerance level (Randall and Tsui, 2002), and whereas at salinity level at high $\mathrm{NaCl}$ concentration the ammoniac toxic effect is lower (Randall and Tsui, 2002; Rodrigues et al., 2007; Fang et al., 2017). Also, in increment condition of sodium and calcium in oxygen saturated water the ammoniac effect decreased (Foss et al., 2007). The TAN toxic effect in water is regulated mainly by $\mathrm{pH}$, temperature, salinity and oxygen (Randall and Tsui, 2002; Gerber et al., 2015; Xiang et al., 2016). One $\mathrm{pH}$ variation of a $25 \%$ can affect significantly the ammoniac concentration (EPA, 1998). This can explain the mortality at low concentration in experimental groups with a $\mathrm{pH}$ variation of \pm 0.2 (Table 2).

Other important topic that has effect on ammonium concentration is the feeding activity. Wicks and Randall (2002) showed that in fish feed, it increases the ammoniac level in plasm, in comparison to the observed level in water, nevertheless in this experiments the fish survived. These results can explain that the fish has glutamine synthesis capacity. Other important factor is the fish capacity for resist the ammoniac concentration under stress conditions (Popovic et al., 2016), then in this scenario Randall and Tsui (2002), showed that the fish during exhaustive exercise and stress incremented its ammonium production and are more sensible to external ammonium. This can be explained by the cortisol increment that is positively related to the glutamine synthesis.

They reported that in Rachycentron canadum juveniles erratic and lethargic swim arised when the fish were exposed to ammoniac concentration of $0.80 \mathrm{NH}_{3} \mathrm{~L}^{-1}$. Similar results to this study were observed in the fifth experimental group exposed to $0.605 \mathrm{NH}_{3} \mathrm{~L}^{-1}$, that has lethargic swim after $24 \mathrm{~h}$. This experimental group was followed by fourth treatment (exposed to $0.325 \mathrm{NH}_{3} \mathrm{~L}^{-1}$ ) and third (exposed to $0.175 \mathrm{NH}_{3} \mathrm{~L}^{-1}$ ) after 48 and $72 \mathrm{hr}$ respectively. The E. maclovinus acute toxicity observed value was of $0.413 \mathrm{NH}_{3} \mathrm{~L}^{-1}$, in conclusion these results would serve of basis for the intensive culture of this species.

\section{Acknowledgements}

The present study was founded by Fundación Chile Project INNOVA-CORFO: Desarrollo tecnológico para el cultivo del róbalo [ = Technological development for Patagonian blenny culture], and MECESUP UCT 0804, and M.I for her valuable comments.

\section{References}

ADAMS, M.B., POWELL, M.D. and PURSER, G.J., 2001. Effect of acute and chronic ammonia and nitrite exposure on oxygen consumption on growth of juvenile big bellied seahorse. Journal of Fish Biology, vol. 58, no. 3, pp. 848-860. http://dx.doi. org/10.1111/j.1095-8649.2001.tb00535.x.

BEAUMONT, M., BUTLER, P. and TAYLOR, E., 1995. Plasma ammonia concentration in brown trout in soft acidic water and its relationship to decreased swimming performance. The Journal 
of experimental biology, vol. 198, no. Pt 10, pp. 2213-2220. PMid:9320125.

CALVO, J., MORRICONI, E., RAE, G.A. and ROMAN, N.A., 1992. Evidence of protandry in a subantarctic notothenid, Eleginops maclovinus, (Cuv. and Val., 1830) from the Beagle channel, Argentina. Journal of Fish Biology, vol. 40, no. 2, pp. 157-164. http://dx.doi.org/10.1111/j.1095-8649.1992.tb02563.x.

CARTER, C.G., HOULIHAN, D.F. and OWEN, S.F., 1998. Protein synthesis, nitrogen excretion and long-term growth of juvenile Pleuronectes flesus. Journal of Fish Biology, vol. 53, pp. 272-284.

EDDY, F., 2005. Ammonia in estuaries and effects on fish. Journal of Fish Biology, vol. 67, no. 6, pp. 1495-1513. http:// dx.doi.org/10.1111/j.1095-8649.2005.00930.x.

FANG, L., BAI, X.-L., LIANG, X.-F., HE, S., GUO, X.-Z., LI, L., LI, B., SHEN, D. and TAO, Y.-X., 2017. Ammonia nitrogen excretion in Mandarin Fish (Siniperca chuatsi) and Grass Carp (Ctenopharyngon idellus) fed practical diets: the effects of water temperature. Aquaculture Research, vol. 48, no. 3, pp. 836-843. http://dx.doi.org/10.1111/are.12927.

FOSS, A., IMSLAND, A.K., ROTH, B., SCHRAM, E. and STEFANSSON, S.O., 2007. Interactive effects of oxygen saturation and ammonia on growth and blood physiology in juvenile turbot. Aquaculture, vol. 271, no. 1-4, pp. 244-251. http:// dx.doi.org/10.1016/j.aquaculture.2007.06.025.

FRANSON, M., 2002. Métodos Normalizados para el análisis de aguas potables y residuales. Madrid: Díaz de Santos Editores, $1816 \mathrm{p}$.

GERBER, R., WEPENER, V. and SMIT, N.J., 2015. Application of multivariate statistics and toxicity indices to evaluate the water quality suitability for fish of three rivers in the Kruger National Park, South Africa. African Journal of Aquatic Science, vol. 40, no. 3, pp. 247-259. http://dx.doi.org/10.2989/16085914.2015.1073139.

HANDY, R.D. and POXTON, M.G., 1993. Nitrogen pollution in mariculture: toxicity and excretion of nitrogenous compounds by marine fish. Reviews in Fish Biology and Fisheries, vol. 3, no. 3, pp. 205-241. http://dx.doi.org/10.1007/BF00043929.

LICANDEO, R.R., BARRIENTOS, C.A. and GONZÁLEZ, M.T., 2006. Age, growth rates, sex change and feeding habits of notothenioid fish Eleginops maclovinus. Environmental Biology of Fishes, vol. 77, no. 1, pp. 51-61. http://dx.doi.org/10.1007/ s10641-006-9054-z.

MIRANDA-FILHO, K.C., WASIELESKY, J.R. and MAÇADA, A.P., 1995. Efeito da amônia e nitrito no crescimento da tainha Mugil platanus (Pisces, mugilidae). Revista Brasileira de Biologia, vol. 55 , pp. $45-50$.

PAVÉZ, H., PEQUEÑO, G., BERTRÁN, C. and VARGAS, L., 2005. Limnetic Feeding of the "Róbalo" Eleginops maclovinus (Valenciennes, 1830) in the Valdivia river, Chile. Interciencia, vol. 30, pp. 120-125.

PERSON, J., RUYET, L., GALLAND, R., ROUX, A. and CHAROTIS, H., 2007. Chronic ammonia toxicity in juvenile turbot (Scophthalmus maximus). Aquaculture, vol. 154, pp. 155-171.

POPOVIĆ, N.T., STRUNJAK-PEROVIĆ, I., BARIŠIĆ, J., KEPEC, S., JADAN, M., BEER-LJUBIĆ, B., MATIJATKO, V., PALIĆ, D., KLOBUČAR, G., BABIĆ, S., KLJUSURIĆ, J.G. and ČOŽRAKOVAC, R., 2016. Native Prussian carp (Carassius gibelio) health status, biochemical and histological responses to treated wastewaters. Environmental Pollution, vol. 218, pp. 689-701. http://dx.doi.org/10.1016/j.envpol.2016.07.063. PMid:27524256.
RAKOCY, J.E., LOSORDO, T.M., and MASSER, M.P. 1992. Recirculating aquaculture tank production systems and overview of critical considerations. Southern Regional Aquaculture Center Publication, no. 454, pp. 1-8.

RANDALL, D.J. and TSUI, T.K.N., 2002. Ammonia toxicity in fish. Marine Pollution Bulletin, vol. 45, no. 1-12, pp. 17-23. http:// dx.doi.org/10.1016/S0025-326X(02)00227-8. PMid:12398363.

RODRIGUES, R.V., SCHWARZ, M.H., DELBOS, B.C. and SAMPAIO, L.A., 2007. Acute toxicity and sublethal effects of ammonia and nitrite for juvenile cobia Rachycentron canadum. Aquaculture, vol. 271, no. 1-4, pp. 553-557. http://dx.doi. org/10.1016/j.aquaculture.2007.06.009.

RUSSO, R.C. and THURSTON, R.V., 1998. Toxicity of ammonia, nitrite and nitrate to fishes. In: D.E. BRUNE and J.R. TOMASSO, eds. Aquaculture and water quality. Baton Rouge: World Aquaculture Society, pp. 58-89.

SA, R., GAVILÁN, M., RIOSECO, M.J., LLANCABURE, A., VARGAS-CHACOFF, L., AUGSBURGER, A. and BAS, F., 2014. Dietary protein requirement of Patagonian blennie (Eleginops maclovinus, Cuvier 1830) juveniles. Aquaculture, vol. 428-429, pp. 125-134. http://dx.doi.org/10.1016/j.aquaculture.2014.02.017.

SHRIVASTAVA, J., SINHA, A.K., CANNAERTS, S., BLUST, R. and BOECK, G., 2017. Temporal assessment of metabolic rate, ammonia dynamics and ion-status in common carp during fasting: a promising approach for optimizing fasting episode prior to fish transportation. Aquaculture, vol. 481, pp. 218-228. http:// dx.doi.org/10.1016/j.aquaculture.2017.09.008

SILVA, M.J.S., COSTA, F.F.B., LEME, F.P., TAKATA, R., COSTA, D.C., MATTIOLI, C.C., LUZ, R.K. and MIRANDA-FILHO, K.C., 2018. Biological responses of neotropical freswhater fish Lophiosilurus alexandri exposed to ammonia and nitrate. The Science of the Total Environment, vol. 616-617, pp. 1566-1575. http://dx.doi.org/10.1016/j.scitotenv.2017.10.157. PMid:29102194.

SOLORZANO, L., 1969. Determination of ammonia in natural waters by the phenolhypochlorite method. Limnology and Oceanography, vol. 14, pp. 799-801.

THURSTON, R.B. and RUSSO, R.C., 1983. Acute toxicity of ammonia to rainbow trout. Transactions of the American Fisheries Society, vol. 112, no. 5, pp. 696-704. http://dx.doi. org/10.1577/1548-8659(1983)112<696:ATOATR>2.0.CO;2.

THURSTON, R.V. and MEYN, E.L., 1984. Acute toxicity of ammonia to five fish species from the northwest United States. Bozeman: Bioassay Laboratory, Montana State University, 13 p. Technical Report, no. 84-4, Fish.

U.S. ENVIRONMENTAL PROTECTION AGENCY - EPA, 1998. Guidelines for risk assessment. Washington: EPA, $114 \mathrm{p}$.

VERBEETEN, B.E., CARTER, C.G. and PURSER, G.J., 1999. The combined effect of feeding time and ratio on growth performance and nitrogen metabolism of greenback flounder. Journal of Fish Biology, vol. 55, no. 6, pp. 1328-1343. http:// dx.doi.org/10.1111/j.1095-8649.1999.tb02079.x.

WAJSBROT, N., GASITH, A., KROM, M.D. and POPPER, D.M., 1991. Acute toxicity of ammonia to juvenile gilthead seabream Sparus auratus under reduced oxygen levels. Aquaculture, vol. 92, pp. 277-288. http://dx.doi.org/10.1016/0044-8486(91)90029-7.

WEIRICH, C.R. and RICHE, M., 2006. Acute tolerance of juvenile Florida pompano, Trachinotus carolinus L., to ammonia and nitrite at various salinities. Aquaculture Research, vol. 37, no. 9, pp. 855-861. http://dx.doi.org/10.1111/j.1365-2109.2006.01502.x. 
WICKS, B., JOENSEN, R., TANG, Q. and RANDALL, J., 2002. Swimming and ammonia toxicity in salmonids: The effect of sub lethal ammonia exposure on the swimming performance of coho salmon and the acute toxicity of ammonia in swimming and resting rainbow trout. Aquatic Toxicology, vol. 59, no. 1-2, pp. 55-69. http:// dx.doi.org/10.1016/S0166-445X(01)00236-3. PMid:12088633.

WICKS, B.J. and RANDALL, D.J., 2002. The effect of sub lethal ammonia exposure on fed and unfed rainbow trout: The role of glutamine in the regulation of ammonia. Comparative Biochemistry and Physiology, vol. 132, no. 2, pp. 275-285. http:// dx.doi.org/10.1016/S1095-6433(02)00034-X. PMid:12020644.
XIANG, L., SUN, T.-F., MO, C.-H., LI, Y.-W., CAI, Q.-Y. and LI, H., 2016. Related environmental problems and research progresses of quaternary ammonium compounds (QACs). Huaxue Jinzhan, vol. 28, pp. 727-736.

ZHOU, Z., LI, H., SONG, C., CAO, X. and ZHOU, Y., 2017. Prevalence of ammonia-oxidizing bacteria over ammoniaoxidizing archea in sediments as related to nutrient loading in Chinese aquaculture ponds. Journal of Soils and Sediments, vol. 17, no. 7, pp. 1928-1938. http://dx.doi.org/10.1007/ s11368-017-1651-2. 